\title{
EVALUATION OF THE SAFETY INTEGRITY LEVEL (SIL) DUE TO THE GUIDELINES OF EN 61508 AND WITH THE USE OF MARKOV PROCESSES
}

\section{OCENA POZIOMU NIENARUSZALNOŚCI \\ BEZPIECZEŃSTWA (SIL) WG NORMY EN 61508 ORAZ Z ZASTOSOWANIEM PROCESÓW MARKOWA}

\author{
Stanisław Młynarski ${ }^{1}$, Robert Pilch², Maksymilian Smolnik ${ }^{2}$, \\ Maciej Szkoda ${ }^{1}$, Jan Szybka \\ ${ }^{1}$ Politechnika Krakowska, ${ }^{2}$ Akademia Górniczo-Hutnicza \\ e-mail:mlynarski_st@poczta.onet.pl; pilch@agh.edu.pl
}

\begin{abstract}
The methods of evaluation of the Probability of Failure on Demand (PFD) of safety systems were presented in the paper, assuming that the safety systems may be represented by the $k$ out of $n$ reliability structures. The results of the calculations obtained according to EN 61508 were compared with another results, this time obtained from the calculations done for these systems assuming that their failure-and-renewal process is a Markov process.
\end{abstract}

Keywords: reliability, safety, SIL

Streszczenie: $W$ artykule przedstawiono metody wyznaczania średniego prawdopodobieństwa nieprawidtowego funkcjonowania (PFD - Probability of Failure on Demand) uktadów systemu zabezpieczeń przyjmują, że posiadaja one elementarne struktury niezawodnościowe typu $k$ z $n$. Uzyskane wg normy EN 61508 wyniki porównano z obliczeniami tych układów zaktadając proces ich uszkodzeń i odnów jako proces Markowa.

Slowa kluczowe: niezawodność, bezpieczeństwo, SIL 
Evaluation of the Safety Integrity Level (SIL) due to the guidelines of EN 61508... Ocena poziomu nienaruszalności bezpieczeństwa (SIL) wg normy EN 61508...

\section{Wstęp}

Do monitorowania procesu eksploatacji systemów, których awarie stanowią zagrożenie dla ludzi i środowiska stosuje się coraz bardziej nowoczesne układy zabezpieczeń. Układy takie o charakterze elektrycznym, elektronicznym i z programowalną elektroniką (E/E/PE) stosowane są $\mathrm{w}$ różnych obszarach skomplikowanych działań technicznych: przy wydobyciu, magazynowaniu i przesyle ropy naftowej oraz gazu, przy wytwarzaniu energii elektrycznej, w przemyśle chemicznym i papierniczym itd. Celem stosowania układów monitorowania i zabezpieczeń jest zmniejszenie ryzyka wynikającego z eksploatacji systemu do poziomu akceptowalnego [1]. Efekt ten jest uzyskiwany poprzez zmniejszenie prawdopodobieństwa wystąpienia zdarzeń niebezpiecznych. O możliwości osiągnięcia wymaganego stopnia obniżenia ryzyka w eksploatowanym systemie decyduje niezawodność zastosowanego układu związanego $\mathrm{z}$ bezpieczeństwem $[4,5]$.

$\mathrm{W}$ artykule przedstawiono metody wyznaczania średniego prawdopodobieństwa nieprawidłowego funkcjonowania (PFD - Probability of Failure on Demand) układów systemu zabezpieczeń przyjmując, że posiadają one elementarne struktury niezawodnościowe typu $k \mathrm{z} n$ i uzyskane wyniki porównano $\mathrm{z}$ obliczeniami tych układów zakładając proces ich uszkodzeń i odnów jako proces Markowa [3,6].

\section{Wyznaczanie poziomu nienaruszalności bezpieczeństwa wg normy EN 61508}

Rzeczywiste systemy składają się z układu technicznego realizującego określone zadania i układów zabezpieczeń. W przypadku, gdy ryzyko, związane z wystąpieniem awarii, generowane przez system nie spełnia oczekiwań, do systemu wprowadzony zostaje układ bezpieczeństwa, gwarantujący zmniejszenie ryzyka awarii do żądanej wartości. Sposób osiągnięcia ryzyka akceptowalnego przedstawiono na rysunku 1.

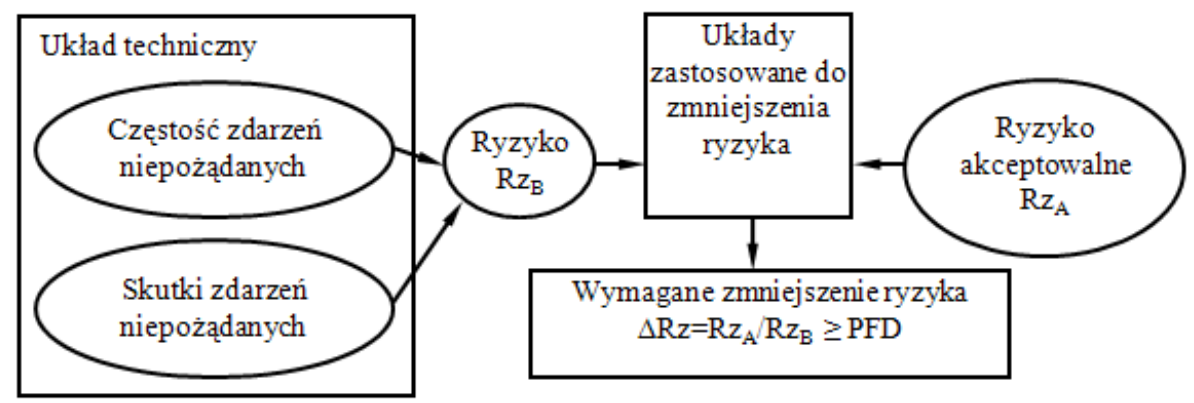

Rys. 1 Sposób osiagnięcia ryzyka akceptowalnego

Ze wzrostem wymagań dotyczących obniżenia ryzyka wzrastają oczekiwania odnośnie do niezawodności, jaką charakteryzować się ma układ związany $\mathrm{z}$ bezpieczeństwem. 
Zgodnie z EN 61508 przyjmuje się 4 charakterystyczne poziomy nienaruszalności bezpieczeństwa (SIL - Safety Integrity Level), które określają dopuszczalne średnie prawdopodobieństwa uszkodzenia układu zastosowanego do zmniejszenia ryzyka. W zależności od częstości pojawiania się zdarzeń niebezpiecznych, rozróżnia się średnie prawdopodobieństwo uszkodzenia w przypadku rzadkich przywołań (PFD) oraz średnie prawdopodobieństwo uszkodzenia w przypadku częstych przywołań (PFH - Probability of Failure on Hour) [1].

Norma EN 61508 przedstawia jedną $\mathrm{z}$ możliwych technik obliczania prawdopodobieństwa uszkodzenia układów związanych $\mathrm{z}$ bezpieczeństwem systemów technicznych. Przedstawiona w przywołanej normie metodyka obliczeń opiera się na kilku zasadniczych założeniach $[1,2,4]$ :

- rozważany układ i wszystkie jego elementy znajdują się w okresie normalnej pracy $\lambda_{i}(t)=$ const.,

- układy związane z bezpieczeństwem są poddawane testom okresowym (co okres $T_{1}$ ), które umożliwiają wykrycie i usunięcie wszystkich uszkodzeń w układzie,

- wykonywane są testy diagnostyczne umożliwiające wykrycie niektórych uszkodzeń,

- intensywność uszkodzeń każdego elementu dzieli się na intensywność uszkodzeń bezpiecznych $\left(\lambda_{S}\right)$ oraz intensywność uszkodzeń niebezpiecznych $\left(\lambda_{D}\right)$,

- część uszkodzeń niebezpiecznych jest wykrywana przez testy diagnostyczne, których skuteczność jest określana jako pokrycie diagnostyczne $(D C)$,

- intensywność uszkodzeń niebezpiecznych $\left(\lambda_{D}\right)$ dzielona jest na intensywność uszkodzeń niebezpiecznych wykrywalnych $\lambda_{D D}=\lambda_{D} D C$ i intensywność uszkodzeń niebezpiecznych niewykrywalnych przez testy diagnostyczne $\lambda_{D U}=\lambda_{D}(1-D C)-$ rysunek 2 ,

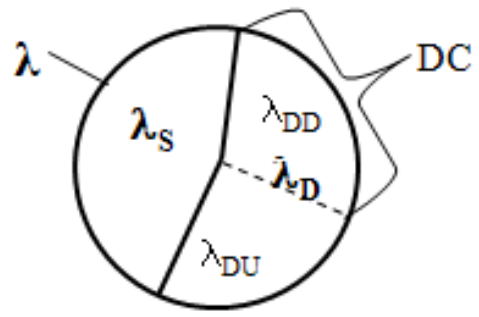

Rys. 2 Intensywność uszkodzeń bezpiecznych i niebezpiecznych oraz wykrywalnych i niewykrywalnych przez testy diagnostyczne

- strukturę układu zabezpieczającego tworzą trzy szeregowo współpracujące podukłady: czujnikowy $(C)$, logiczny $(L)$ i wykonawczy $(W)$, z których każdy posiada odpowiednią strukturę $k \mathrm{z} n$, 
Evaluation of the Safety Integrity Level (SIL) due to the guidelines of EN 61508... Ocena poziomu nienaruszalności bezpieczeństwa (SIL) wg normy EN 61508...

- prawdopodobieństwa uszkodzenia każdego z podukładów obliczane są oddzielnie wg tych samych zasad, a końcowe średnie prawdopodobieństwo uszkodzenia wyznaczane jest z zależności:

$$
P F D=P F D_{C}+P F D_{L}+P F D_{W}
$$

- średni czas naprawy każdego elementu wynosi, w przypadku uszkodzeń wykrywalnych: $M T T R=\frac{1}{\mu_{D D}}$, a w przypadku uszkodzeń niewykrywalnych: $\frac{T_{1}}{2}+\operatorname{MTTR}=\frac{1}{\mu_{D U}}[1,2,4]$.

Poniżej przedstawiono schematy blokowe podstawowych struktur $k \mathrm{z} n$, dla których wykonano obliczenia PFD zgodnie z EN 61508.

Struktura $1 \mathrm{z} 1$ składa się z jednego elementu, który przez czas $t_{C l}$ może przebywać w stanie niezdatności ze względu na uszkodzenie niebezpieczne niewykrywalne oraz przez czas $t_{C 2}$ ze względu na uszkodzenie niebezpieczne wykrywalne przez testy diagnostyczne. Łącznie daje to średni czas przebywania w stanie niezdatności określony jako $t_{C E}[1,2,4]$.

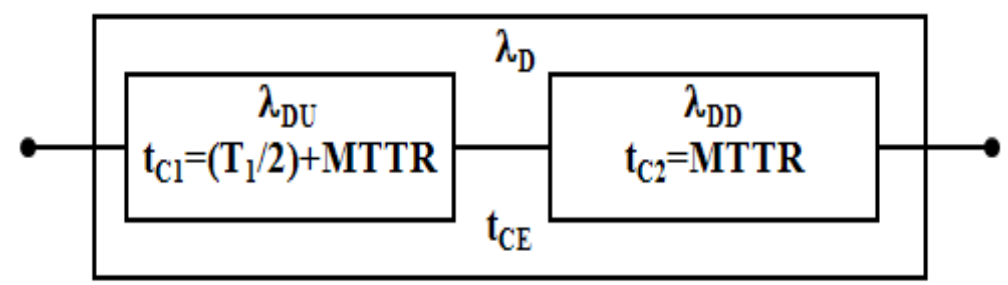

Rys. 3 Schemat blokowy dla pojedynczego elementu oraz struktury 1 z 1

$$
t_{C E}=\frac{\lambda_{D U}}{\lambda_{D}}\left(\frac{T_{1}}{2}+M T T R\right)+\frac{\lambda_{D D}}{\lambda_{D}} M T T R
$$

Średnie prawdopodobieństwo uszkodzenia układu wyraża się jako:

$$
P F D=1-e^{-\lambda_{D} t_{C E}}
$$

ponieważ $\lambda_{D} t_{C E} \ll 1$, przyjmuje się, że można w przybliżeniu zapisać:

$$
P F D=\lambda_{D} t_{C E}=\left(\lambda_{D U}+\lambda_{D D}\right) t_{C E}
$$

Dla dowolnej struktury $n \mathrm{z} n$ zależność przyjmie postać:

$$
P F D=n\left(\lambda_{D U}+\lambda_{D D}\right) t_{C E}=n \lambda_{D} t_{C E}
$$

Dla wszystkich struktur $k \mathrm{z} n$, gdy $k<n$, schemat blokowy można w sposób ogólny przedstawić jak na rysunku 4. 
Stanisław Młynarski, Robert Pilch, Maksymilian Smolnik, Maciej Szkoda, Jan Szybka

Wartość czasu $t_{C E}$ wyznaczana jest w tych przypadkach wg (2), natomiast średni czas przebywania $\mathrm{w}$ stanie niezdatności $n-k+1$ elementów układu $\left(t_{G E}\right)$ zgodnie z zależnością:

$$
t_{G E}=\frac{\lambda_{D U}}{\lambda_{D}}\left(\frac{T_{1}}{n-k+2}+M T T R\right)+\frac{\lambda_{D D}}{\lambda_{D}} M T T R
$$

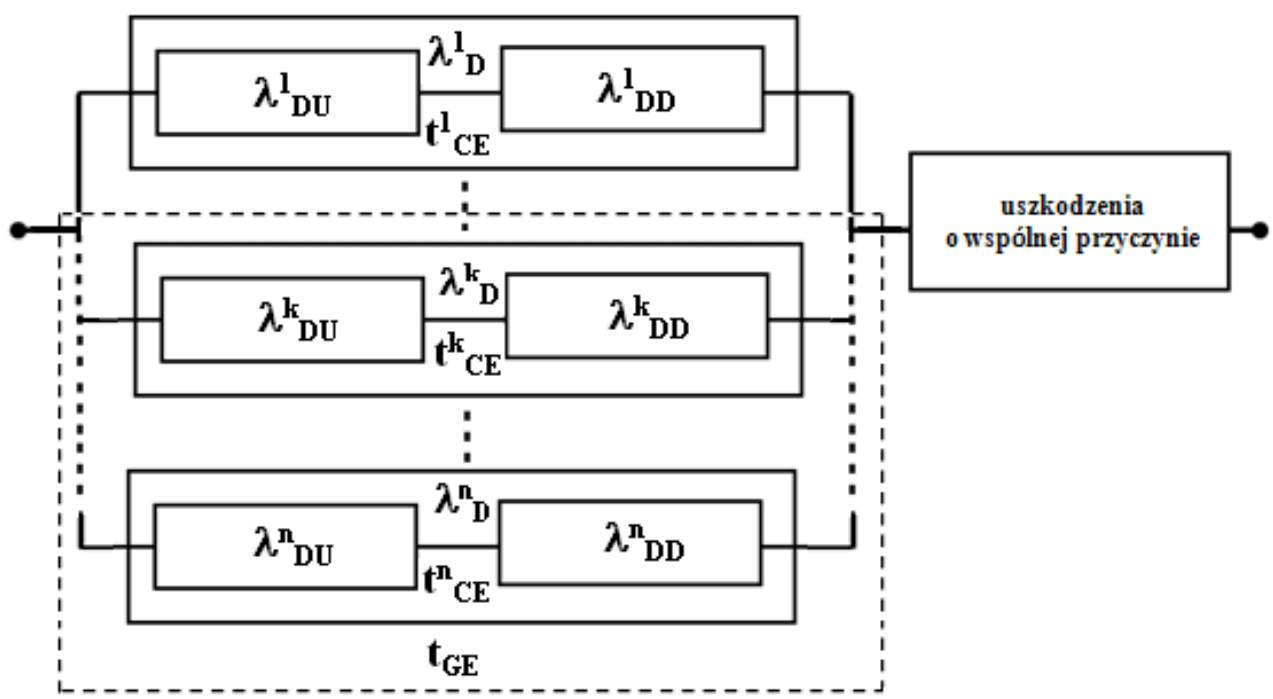

Rys. 4 Uogólniony schemat blokowy struktur $k z$ $n$ gdy $k<n$

Występujący na schemacie blok uszkodzeń o wspólnej przyczynie odzwierciedla możliwość pojawienia się uszkodzeń o wspólnej dla wszystkich elementów przyczynie, które spowodują niezdatność całego układu. W poniższych zależnościach są one reprezentowane jako udział uszkodzeń niewykrytych o wspólnej przyczynie $(\beta)$ oraz udział uszkodzeń o wspólnej przyczynie wykrytych przez testy diagnostyczne $\left(\beta_{D}\right)$. Średnie prawdopodobieństwa wystąpienia uszkodzenia podstawowych struktur $k \mathrm{z} n$, gdy $k<n$, przedstawiają poniższe zależności $[1,2,4]$ :

- dla struktury 1 z 2 :

$$
\begin{gathered}
P F D=2\left(\left(1-\beta_{D}\right) \lambda_{D D}+(1-\beta) \lambda_{D U}\right)^{2} t_{C E} t_{G E}+\beta_{D} \lambda_{D D} M T T R+ \\
+\beta \lambda_{D U}\left(\frac{T_{1}}{2}+M T T R\right)
\end{gathered}
$$

- dla struktury 1 z 3:

$$
\begin{gathered}
P F D=3\left(\left(1-\beta_{D}\right) \lambda_{D D}+(1-\beta) \lambda_{D U}\right)^{3} t_{C E}^{2} t_{G E}+\beta_{D} \lambda_{D D} M T T R+ \\
+\beta \lambda_{D U}\left(\frac{T_{1}}{2}+M T T R\right)
\end{gathered}
$$


Evaluation of the Safety Integrity Level (SIL) due to the guidelines of EN 61508... Ocena poziomu nienaruszalności bezpieczeństwa (SIL) wg normy EN 61508...

- dla struktury 2 z 3 :

$$
\begin{aligned}
P F D=6\left(\left(1-\beta_{D}\right) \lambda_{D D}\right. & \left.+(1-\beta) \lambda_{D U}\right)^{2} t_{C E} t_{G E}+\beta_{D} \lambda_{D D} M T T R+ \\
& +\beta \lambda_{D U}\left(\frac{T_{1}}{2}+M T T R\right)
\end{aligned}
$$

- dla struktury 4 z 6 :

$$
\begin{gathered}
P F D=60\left(\left(1-\beta_{D}\right) \lambda_{D D}+(1-\beta) \lambda_{D U}\right)^{3} t_{C E}^{2} t_{G E}+\beta_{D} \lambda_{D D} M T T R+ \\
+\beta \lambda_{D U}\left(\frac{T_{1}}{2}+M T T R\right)
\end{gathered}
$$

\section{Proces Markowa}

Wyliczone wg normy EN 61508 wartości prawdopodobieństw PFD porównano z obliczeniami niezawodności powyżej przedstawionych struktur, przyjmując proces uszkodzeń i odnów ich elementów jako proces Markowa [3,6].

Poniżej przedstawiono fragment przeprowadzonych analiz na przykładzie struktury najprostszej $1 \mathrm{z} 1$ oraz struktury $1 \mathrm{z} 2$. Wszystkie przedstawione $\mathrm{w}$ rozdziale czwartym wyniki obliczeń numerycznych badanych struktur zostały opracowane w analogiczny sposób.

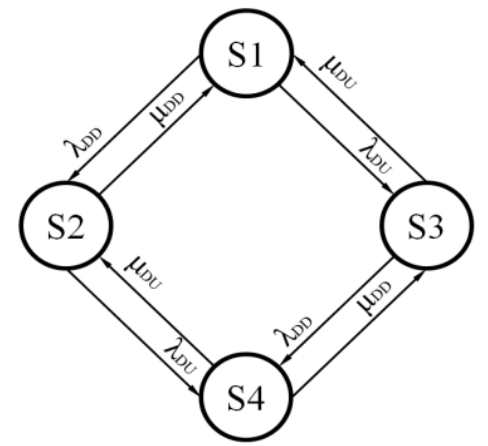

Rys. 5 Graf przejść między stanami w uktadzie o strukturze 1 z 1

Równania Kołmogorowa dla układu o strukturze 1 z 1 przedstawiają się następująco:

$$
\left\{\begin{array}{l}
\frac{\mathrm{d} p_{1}(t)}{\mathrm{d} t}=-\left(\lambda_{D D}+\lambda_{D U}\right) \cdot p_{1}(t)+\mu_{D D} \cdot p_{2}(t)+\mu_{D U} \cdot p_{3}(t) \\
\frac{\mathrm{d} p_{2}(t)}{\mathrm{d} t}=-\left(\lambda_{D U}+\mu_{D D}\right) \cdot p_{2}(t)+\lambda_{D D} \cdot p_{1}(t)+\mu_{D U} \cdot p_{4}(t) \\
\frac{\mathrm{d} p_{3}(t)}{\mathrm{d} t}=-\left(\lambda_{D D}+\mu_{D U}\right) \cdot p_{3}(t)+\lambda_{D U} \cdot p_{1}(t)+\mu_{D D} \cdot p_{4}(t) \\
\frac{\mathrm{d} p_{4}(t)}{\mathrm{d} t}=-\left(\mu_{D D}+\mu_{D U}\right) \cdot p_{4}(t)+\lambda_{D U} \cdot p_{2}(t)+\lambda_{D D} \cdot p_{3}(t)
\end{array}\right.
$$


W układzie o strukturze 1 z 2 można wyróżnić szesnaście stanów niezawodnościowych. Stosując redukcję (połączenie) podobnych stanów ze względu na niezawodność poszczególnych elementów, ich liczbę ograniczono do dziesięciu. Poniżej przedstawiono graf przejść między stanami i wynikający z nich fragment układu równań Kołmogorowa.

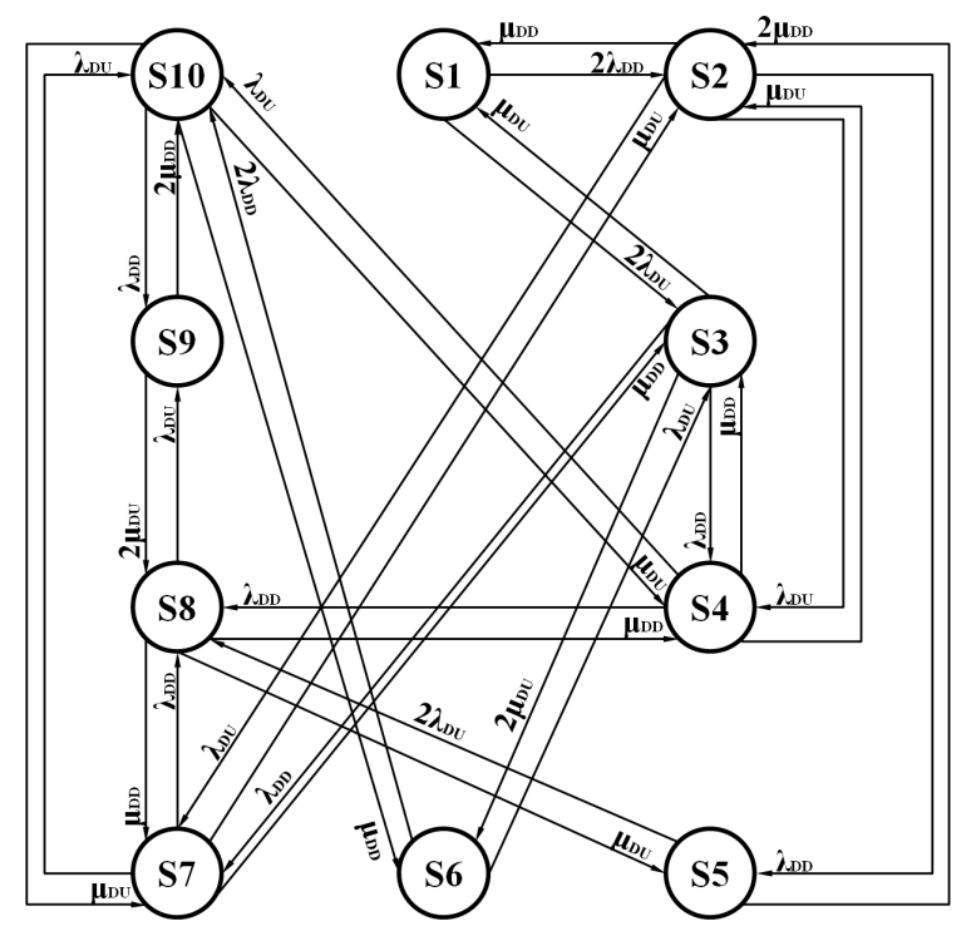

Rys. 6 Graf przejść między stanami w układzie o strukturze 1 z 2

Fragment układu równań struktury 1 z 2 po przeprowadzonej redukcji:

$$
\left\{\begin{array}{c}
\frac{\mathrm{d} p_{1}(t)}{\mathrm{d} t}=-\left(2 \lambda_{D D}+2 \lambda_{D U}\right) \cdot p_{1}(t)+\mu_{D D} \cdot p_{2}(t)+\mu_{D U} \cdot p_{3}(t) \\
\frac{\mathrm{d} p_{2}(t)}{\mathrm{d} t}=-\left(\lambda_{D D}+2 \lambda_{D U}+\mu_{D D}\right) \cdot p_{2}(t)+2 \lambda_{D D} \cdot p_{1}(t)+\mu_{D U} \cdot p_{4}(t)+ \\
+2 \mu_{D D} \cdot p_{5}(t)++\mu_{D U} \cdot p_{7}(t) \\
\cdots \\
\frac{\mathrm{d} p_{10}(t)}{\mathrm{d} t}=-\left(\lambda_{D D}+\mu_{D D}+2 \mu_{D U}\right) \cdot p_{10}(t)+\lambda_{D U} \cdot p_{4}(t)+2 \lambda_{D D} \cdot p_{6}(t) \\
+\lambda_{D U} \cdot p_{7}(t)+2 \mu_{D D} \cdot p_{9}(t)
\end{array}\right.
$$


Evaluation of the Safety Integrity Level (SIL) due to the guidelines of EN 61508... Ocena poziomu nienaruszalności bezpieczeństwa (SIL) wg normy EN 61508...

Przedstawiona powyżej, w uproszczonej formie, metodyka przeprowadzenia analizy stanów niezawodnościowych została wykorzystana w obliczeniach numerycznych, których wyniki zamieszczono w rozdziale czwartym.

\section{Przykład obliczeniowy}

Do przeprowadzenia obliczeń i porównania ich wyników wybrano kilka podstawowych struktur $k \mathrm{z} n$, składających się $\mathrm{z}$ obiektów pojedynczych, jednakowych pod względem funkcjonalnym i niezawodnościowym. Celem prowadzonych analiz jest ocena prawdopodobieństwa pozostawania $\mathrm{w}$ stanie niezdatności całego systemu, a nie jego pojedynczych elementów. Wobec tego, kryterium zdatności systemu to jednoczesny brak uszkodzeń wykrywalnych i niewykrywalnych w obiektach, których liczba nie przekroczy wartości większej niż $n-k$.

Obliczenia PFD wg EN 61508 dokonano wg zależności (2) i (5)-(10). W celu umożliwienia porównania wyników, w obliczeniach wg normy nie uwzględniono uszkodzeń o wspólnej przyczynie. Obliczenia przeprowadzono również przy wykorzystaniu modeli opartych na procesach Markowa. Poniżej scharakteryzowano każdy z nich.

Model „A" jest modelem, w którym przyjęto, tak jak w normie, podział intensywności uszkodzeń na wynikającą $z$ uszkodzeń niebezpiecznych wykrywalnych i uszkodzeń niebezpiecznych niewykrywalnych przez testy diagnostyczne $\left(\lambda_{D D}, \lambda_{D U}\right)$. W każdym obiekcie mogą występować uszkodzenia jednego i drugiego rodzaju, więc może być on uszkodzony na dwa sposoby jednocześnie. Podobny podział przyjęto dla intensywności odnowy uszkodzonych w odpowiedni sposób elementów:

$$
\begin{gathered}
\mu_{D D}=M_{T T R^{-1}} \\
\mu_{D U}=\left(\frac{T_{1}}{2}+M T T R\right)^{-1}
\end{gathered}
$$

Każda odnowa dotyczy usunięcia uszkodzenia tylko jednego rodzaju.

W modelu nie występuje klasyczny stan pochłaniania, lecz uwzględniane są wszystkie możliwe stany niezdatności, z których zakłada się możliwość powrotu do stanu zdatności. Graf stanów oraz równania różniczkowe dla układów 1 z 1 oraz 1 z 2 przedstawiono na rysunkach 5 i 6 . W wyniku obliczeń otrzymuje się prawdopodobieństwo przebywania układu w stanach zdatności $A(\Delta t)$ lub niezdatności $P(\Delta t)=1-A(\Delta t) . \quad \mathrm{Na}$ tej podstawie wyznaczono średnie prawdopodobieństwo przebywania układu $\mathrm{W}$ stanie niezdatności według zależności:

$$
P F D^{A}=\frac{1}{n} \cdot \sum_{i=1}^{i=n} P\left(t_{i}\right)
$$

Model „B” stanowi uproszczenie modelu „A”. Przyjęto w nim jeden rodzaj intensywności uszkodzeń elementów, który jest sumą intensywności uszkodzeń wykrywalnych i niewykrywalnych w testach diagnostycznych:

$$
\lambda_{D}=\left(\lambda_{D U}+\lambda_{D D}\right)
$$


oraz jedną intensywność ich odnowy $\mu_{D}$ :

$$
\begin{aligned}
\mu_{D}= & \left(t_{C E}\right)^{-1}=\left(\frac{\lambda_{D U}}{\lambda_{D}}\left(\frac{T_{1}}{2}+M T T R\right)+\frac{\lambda_{D D}}{\lambda_{D}} M T T R\right)^{-1}= \\
= & \left((1-D C)\left(\frac{T_{1}}{2}+M T T R\right)+D C \cdot M T T R\right)^{-1}
\end{aligned}
$$

W modelu uwzględniono wszystkie możliwe stany zdatności oraz niezdatności. Średnie prawdopodobieństwo przebywania w stanie niezdatności $\left(P F D^{B}\right)$ wyznaczono wg zależności (13). Graf stanów dla układu 1 z 2 przedstawiono na rysunku 7.

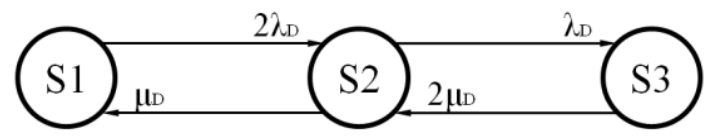

\section{Rys. 7 Graf przejść między stanami w uktadzie o strukturze 1 z 2 wg modelu B}

Model „C” jest najbliższy klasycznemu modelowi Markowa. Założono, jak w modelu „A", dwa rodzaje intensywności uszkodzeń każdego elementu $\left(\lambda_{D D}, \lambda_{D U}\right)$ oraz odpowiednie intensywności odnowy $\left(\mu_{D D}, \mu_{D U}\right)$. Przyjęto jednak stan pochłaniania, z którego nie ma powrotu do stanów zdatności. W wyniku obliczeń otrzymuje się wartości niezawodności lub dystrybuanty w przedziale od 0 do $T_{1}$. Do porównania $\mathrm{z}$ innymi modelami brane pod uwagę są średnie wartości dystrybuanty, wyznaczane według zależności:

$$
P F D^{C}=\frac{1}{n} \cdot \sum_{i=1}^{i=n} F\left(t_{i}\right)
$$

Do przeprowadzenia obliczeń według normy oraz opisanych wariantów procesów Markowa przyjęto następujące dane: $\lambda_{D}=1,66 \cdot 10^{-6}\left[\mathrm{~h}^{-1}\right] ; D C=0,93 ; T_{1}=17520[\mathrm{~h}]$; $M T T R=24[\mathrm{~h}] ; \mu_{D D}=0,0417\left[\mathrm{~h}^{-1}\right] ; \mu_{D U}=0,1138 \cdot 10^{-3}\left[\mathrm{~h}^{-1}\right] ; \mu_{D}=1,573 \cdot 10^{-3}\left[\mathrm{~h}^{-1}\right] ;$ $\beta=\beta_{D}=0$, a wyniki obliczeń przedstawiono na rysunku 8 .

Po dokonaniu obliczeń można zauważyć, że model Markowa A, który wydaje się być najdokładniejszy i najlepiej odzwierciedlający rzeczywiste układy, daje najniższe wartości prawdopodobieństwa uszkodzenia. Jednak wyznaczenie stanów i określenie równań dla układów $\mathrm{z}$ większą liczbą elementów jest czasochłonne (np. dla struktury 2 z 3 występuja, przed redukcją, 64 stany systemu). Według obliczeń przeprowadzonych na podstawie normy prawdopodobieństwa uszkodzenia są znacznie wyższe niż w modelu A, gdyż wszelkie zaokrąglenia i uproszczenia są $\mathrm{w}$ normie przyjmowane zawsze w kierunku bezpiecznym. Najbliższe wartościom uzyskanym na podstawie normy są wartości prawdopodobieństw uzyskane według modelu B.

Są one dla odpowiednich struktur zawsze mniejsze od wartości uzyskanych według normy, ale większe niż w modelu A. 
Evaluation of the Safety Integrity Level (SIL) due to the guidelines of EN 61508... Ocena poziomu nienaruszalności bezpieczeństwa (SIL) wg normy EN 61508...

Model B w mniejszym stopniu niż norma przeszacowuje zagrożenie wystąpienia uszkodzenia. Ponadto budowa grafu i równań jest w tym modelu bardzo prosta, niezależnie od liczby elementów $k$ i $n$.

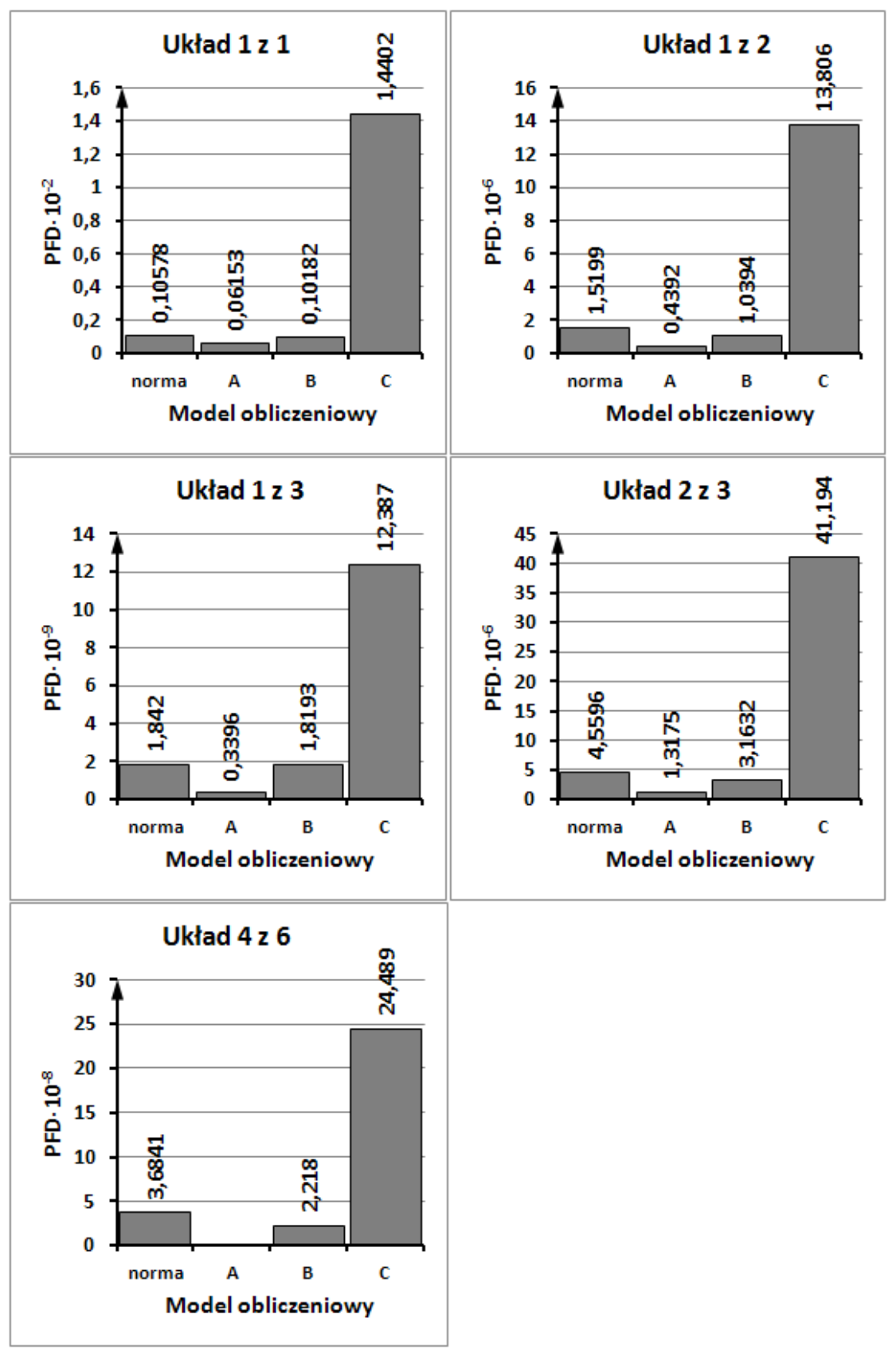

Rys. 8 Histogramy wyników obliczeń 
Stanistaw Młynarski, Robert Pilch, Maksymilian Smolnik, Maciej Szkoda, Jan Szybka

Wyniki obliczeń numerycznych zestawiono w tabeli 1.

Tabela 1. Średnie prawdopodobieństwa uszkodzenia PFD wedlug różnych modeli obliczeniowych

\begin{tabular}{|c|r|r|r|c|}
\hline \multirow{2}{*}{$\begin{array}{c}\text { Struktura } \\
k \text { z } n\end{array}$} & \multicolumn{4}{|c|}{ Model obliczeniowy } \\
\cline { 2 - 5 } & $\begin{array}{c}\text { Norma } \\
\text { EN 61508 }\end{array}$ & $\begin{array}{c}\text { Model } \\
\text { Markowa A }\end{array}$ & $\begin{array}{c}\text { Model } \\
\text { Markowa B }\end{array}$ & $\begin{array}{c}\text { Model } \\
\text { Markowa C }\end{array}$ \\
\hline 1 z 1 & $1,0578 \cdot 10^{-3}$ & $0,6153 \cdot 10^{-3}$ & $1,0182 \cdot 10^{-3}$ & $14,402 \cdot 10^{-3}$ \\
\hline 1 z 2 & $1,5199 \cdot 10^{-6}$ & $0,4392 \cdot 10^{-6}$ & $1,0394 \cdot 10^{-6}$ & $13,806 \cdot 10^{-6}$ \\
\hline 1 z 3 & $1,842 \cdot 10^{-9}$ & $0,3396 \cdot 10^{-9}$ & $1,8193 \cdot 10^{-9}$ & $12,387 \cdot 10^{-9}$ \\
\hline 2 z 3 & $4,5596 \cdot 10^{-6}$ & $1,3175 \cdot 10^{-6}$ & $3,1632 \cdot 10^{-6}$ & $41,194 \cdot 10^{-6}$ \\
\hline 4 z 6 & $3,6841 \cdot 10^{-8}$ & & $2,218 \cdot 10^{-8}$ & $24,489 \cdot 10^{-8}$ \\
\hline
\end{tabular}

Model $\mathrm{C}$ daje zdecydowanie najwyższe ze wszystkich wartości prawdopodobieństw uszkodzenia układów. Wynika to z faktu że nie występuje w tym modelu możliwość powrotu układu ze stanu niezdatności do stanów zdatności. Wyniki uzyskane zgodnie z procedurą obliczeniową tego modelu są prawdopodobieństwem, że w zadanym przedziale czasu układ znajdzie się w stanie niezdatności.

\section{Wnioski}

Analiza uzyskanych wyników potwierdza, że obliczenia prawdopodobieństwa uszkodzenia PFD dają podobne rezultaty, gdy prowadzone są według normy EN 61508 oraz przy pomocy modeli Markowa. Istotna różnica wyników występuje dla modelu obliczeniowego typu $\mathrm{C}$, gdzie wprowadzony jest stan pochłaniający (uszkodzenia systemu), $\mathrm{z}$ którego nie ma powrotu. Jest on wariantem pesymistycznym i w sytuacjach, w których pożądane jest wysokie bezpieczeństwo eksploatacji systemu, powinien być on stosowany niezależnie od obliczeń przeprowadzonych zgodnie $\mathrm{z}$ normą EN 61508. System związany $\mathrm{z}$ bezpieczeństwem zapewnia wyłącznie nadzór nad funkcjonowaniem systemu technicznego, a jego uszkodzenie nie wyklucza poprawności funkcjonowania kontrolowanego układu.

\section{Literatura}

[1] EN 61508 - Bezpieczeństwo funkcjonalne elektrycznych (elektronicznych) programowalnych elektronicznych systemów związanych z bezpieczeństwem, 2010.

[2] Guo H., Yang X.: A simple reliability block diagram method for safety integrity verification, Reliability Engineering and System Safety, 92/2007, $1267-1273$. 
Evaluation of the Safety Integrity Level (SIL) due to the guidelines of EN 61508... Ocena poziomu nienaruszalności bezpieczeństwa (SIL) wg normy EN 61508...

[3] Bukowski J.V., Goble W.M.: Using Markov models for safety analysis of programmable electronic systems, ISA Transactions, 34/1995, 193 - 198.

[4] Zhang T., Long W., Sato Y..: Availability of systems with self-diagnostic components - applying Markov model to IEC 61508-6, Reliability Engineering and System Safety, 80/2003, $133-141$.

[5] Młynarski S. Oprzędkiewicz J.: Systemowe rozwiązania zapewnienia bezpieczeństwa i niezawodności obiektów technicznych, Problemy Eksploatacji, Maintenance Problems, 3/2012, 39-54.

[6] Szybka J.: Methodology for reliability estimation of systems with sliding reserve, Scientific Problems of Machines Operation and Maintenance, $3(163) / 2010,65-73$.

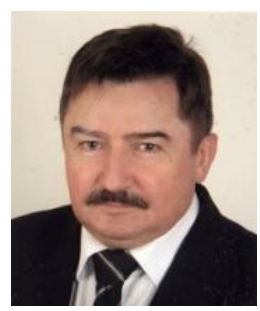

Dr inż. Stanistaw Mhynarski ukończyt studia na Wydziale Mechanicznym Politechniki Krakowskiej. Odbyt 2 letni staż zawodowy w NY USA w Zaktadach Mechaniki Precyzyjnej.

Ukończyt studia doktoranckie na Wydziale Mechanicznym PK i uzyskat stopień doktora nauk technicznych. Obecnie pracownik naukowo-dydaktyczny Politechniki Krakowskiej na stanowisku adiunkta. Specjalizuje się $w$ dziedzinie eksploatacji, niezawodności oraz bezpieczeństwa maszyn, pojazdów i systemów technicznych.

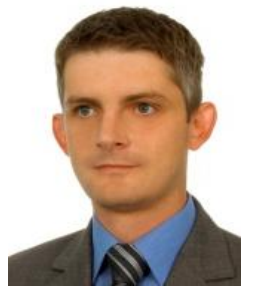

Dr inż. Robert Pilch ukończyt studia na Wydziale Inżynierii Mechanicznej i Robotyki AGH w Krakowie oraz uzyskat stopień doktora nauk technicznych. Pracownik naukowo-dydaktyczny (adiunkt), WIMiR, AGH. Zainteresowania naukowe: niezawodność $i$ eksploatacja maszyn, bezpieczeństwo systemów technicznych, niezawodność układów sieciowych, odnawianie profilaktyczne obiektów technicznych.

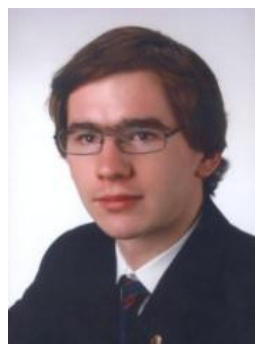

Mgr inz. Maksymilian Smolnik ukończyt studia na Wydziale Inżynierii Mechanicznej i Robotyki, AGH w Krakowie. Obecnie uczestniczy $w$ studiach doktoranckich na WIMiR, AGH. Pracownik naukowo-dydaktyczny (asystent) WIMiR, AGH. Zainteresowania naukowe: budowa $i$ eksploatacja maszyn zwłaszcza pojazdów szynowych i samochodowych, niezawodność systemów technicznych, metodologia projektowania systemów i procesów.

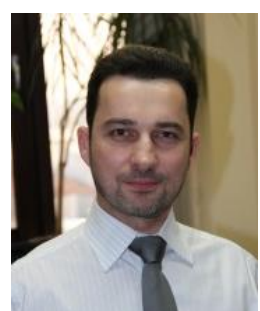

Dr inz. Maciej Szkoda ukończyt studia na Wydziale Mechanicznym PK w Krakowie gdzie uzyskat stopień doktora nauk technicznych. Pracownik naukowo-dydaktyczny w Instytucie Pojazdów Szynowych Politechniki Krakowskiej. Zainteresowania naukowe: niezawodność, bezpieczeństwo i utrzymanie pojazdów szynowych, ocena efektywności środków transportu. 